\title{
$\bullet$ \\ Comparative Study of Initial Transmission Rate of CORONA Virus Among the Countries
}

\author{
IJCRR \\ Section: Healthcare \\ ISI Impact Factor \\ (2019-20): 1.628 \\ IC Value (2019): 90.81 \\ $\operatorname{SJIF}(2020)=7.893$

Varalakshmi V1, Sunil Kumar K²

'Professor, Department of Civil Engineering, Marri Laxman Reddy lnstitute of Technology and Management, Hyderabad, Telangana State,

India; ${ }^{2}$ Professor, Department of Pharmacology, Marri Laxman Reddy lnstitute of Pharmacy, Hyderabad, Telangana State, India.

\section{ABSTRACT}

Introduction: Coronavirus disease 2019 (COVID-19) is a pandemic disease caused by severe acute respiratory syndrome coronavirus 2 (SARS-CoV-2). The disease was first identified in December 2019 in Wuhan and spread in 216 countries due to airborne transmission. But the transmission rate is low in some of the countries and large in a few countries like Italy Iran, Japan, India, the USA etc.

Objective: The present paper focuses on the study of the transmission speed of COVID-19 cases. But it is observed that up to $5^{\text {th }}$ march the total daily number of cases conformed is below 1000 from various countries where it is now raised to more than 75,000 .

Methods: 14 countries case studies are taken depend on the data availability, the first case reported in the last week of January or the first week of February and the severity of the outbreak of COVID-19. The daily reported number of Covid-19 cases for each country is collected from the WHO Daily reports. The data is converted into a graphical form. The selected countries are divided into three groups. The first group contain the cases reported below 10,000 on $16^{\text {th }}$ April 2020 , the second group reported the cases between 10,000 to 50000 on or before $16^{\text {th }}$ April and the third group reported above 50,000 cases on $16^{\text {th }}$ April 2020 .

Results: Sudden rise in cases take place from $12^{\text {th }}$ March 2020 to date over the entire globe. From the available data, it is also observed that the number of countries infected also drastically increased in March 2020.

Conclusion: It is also observed that in nearly the first 40-50 days the transmission rate of coronavirus is very low and confirmed cases reporting have travel history. After that, the local transmission took place which led to the sudden rise in confirmed cases.

Key Words: Coronavirus, Transmission rate, Countries, Case studies, COVID-19, Travel history

\section{INTRODUCTION}

Coronavirus disease 2019 (COVID-19) is a pandemic disease caused by severe acute respiratory syndrome coronavirus 2 (SARS-CoV-2). ${ }^{1-4}$ The disease was first identified in December 2019 in Wuhan, the capital of China's Hubei province. Now it spread in 216 countries due to airborne transmission. To break the COVID-19 World Health Organization (WHO) declared the 2019-20 Public Health Emergency of International Concern on $30^{\text {th }}$ January 2020 and a pandemic on $11^{\text {th }}$ March $2020.60 \%$ of the world population is affected due to covid-19 disease till now. But the transmission rate is low in some of the countries and large in few countries like Italy Iran, Japan, India, the USA from the who reports the first coronavirus case is reported outside the china was on $13^{\text {th }}$ January $2020 .^{5-7}$

It is observed that up to $5^{\text {th }}$ march the total daily number of cases conformed is below 1000 from various countries where it is now raised to more than 75,000 . Sudden rise in cases takes place from $12^{\text {th }}$ March 2020 to date over the entire globe. From the available data, it is also observed that the number of countries infected also drastically increased in March 2020. The fast-spreading of the virus around the globe is possible due to its mutated nature and the size of the tiny virus particle. Before the severe virus outbreak, the genetic nature of corona make a slight change from country to country and location to location for the survival of the virus in different climatic conditions. ${ }^{8}$

\section{Corresponding Author:}

Varalakshmi V, Professor, Department of Civil Engineering, Marri Laxman Reddy Institute of Technology and Management, Hyderabad, Telangana State, India; Email: varasays@gmail.com

ISSN: 2231-2196 (Print) ISSN: 0975-5241 (Online)

Received: 06.11 .2020 Revised: 12.01 .2021 Accepted: 18.03 .2021 Published: 30.03 .2021 
Due to this reason, the virus existing in all climatic conditions and the virus spreading rate is very low initially. ${ }^{9}$

For detail analyzing the spreading speed of the virus and its reasons, 14 countries case studies are taken depend on the data availability, the first case reported in the last week of January or first week of February and severity of the outbreak of COVID-19. The selected countries are divided into three groups.

\section{SPREADING BEHAVIOUR OF CORONAVIRUS IN VARIOUS COUNTRIES}

\section{Group-1: The cases reported below 10,000 on $16^{\text {th }}$ April 2020}

Thailand: On 13 January 2020, Thailand conformed first imported novel corona case and a totally of 2672 people are infected on or before $16^{\text {th }}$ April 2020. Initially, the spread is slow until 14 $4^{\text {th }}$ March 2020 (i.e,61 days increment of cases is slow). The number of cases is low on the island due to it declare a 30days state emergency on $26^{\text {th }}$ March 2020 to combat the covid-19 virus. At the time of declaring an emergency, the number of cases reported is 934 . Imposing restrictions to travel and shutdown the non-essential business Thailand get success in decreasing the surge of the COVID-19 cases. $^{10}$

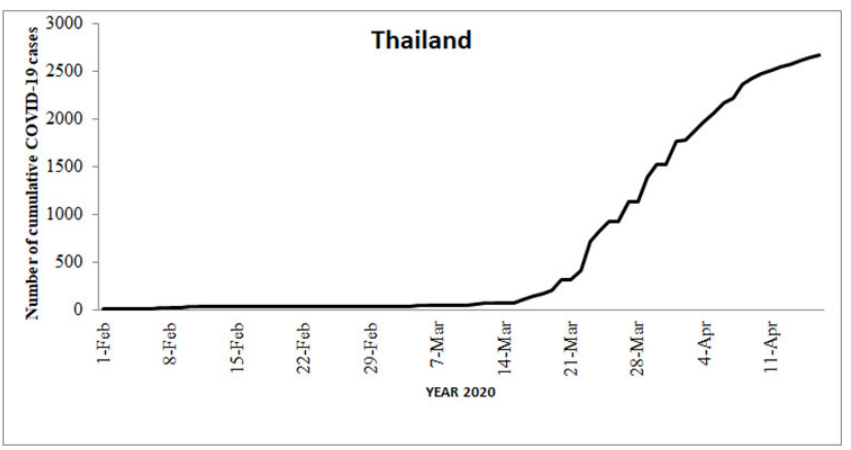

Figure 1: Variation of COVID-19 cases confirmed in Thailand based on WHO report.

Japan: Japan was the second country to report conformed first imported novel corona case on $16^{\text {th }}$ January 2020.The increase in number of cases is slow till $29^{\text {th }}$ February 2020 (total of 45 days). Japan currently experiences cold climate with temperatures falling below $0^{\circ}$ making infection control difficult. The Japanese government, make actions such as closing schools and restricting inbound travel from coronavirus-affected countries to reduce the effect of novel coronavirus, till more than or equal 500 cases are conforming daily.

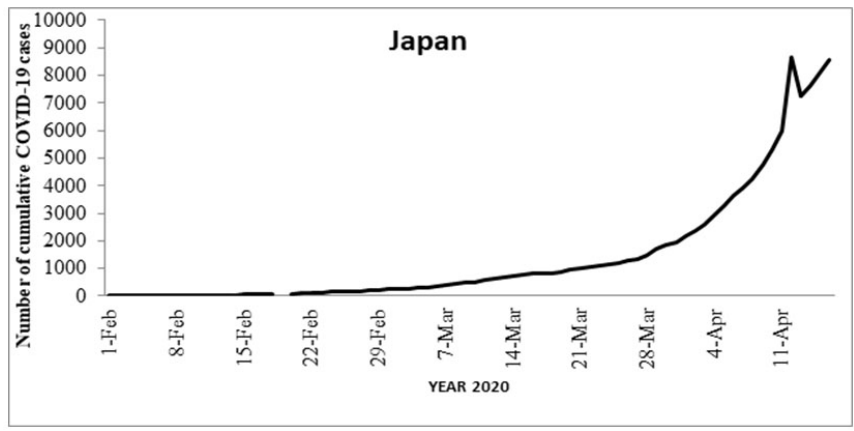

Figure 2: Variation of COVID-19 cases confirmed in Japan based on the $\mathrm{WHO}$ report.

Singapore: Singapore was one of the earliest countries to detect COVID-19. Singapore's government announced a one-month lockdown on $3^{\text {rd }}$ April 2020 which include the shutter of schools and most workplaces to break the circuit of coronavirus spread. According to a WHO report Singapore has conformed 1049 corona cases at the time of lockdown. From Figure 3 it is observed that the increment rate is low up to $9^{\text {th }}$ March 2020 and it increased drastically from $14^{\text {th }}$ March 2020

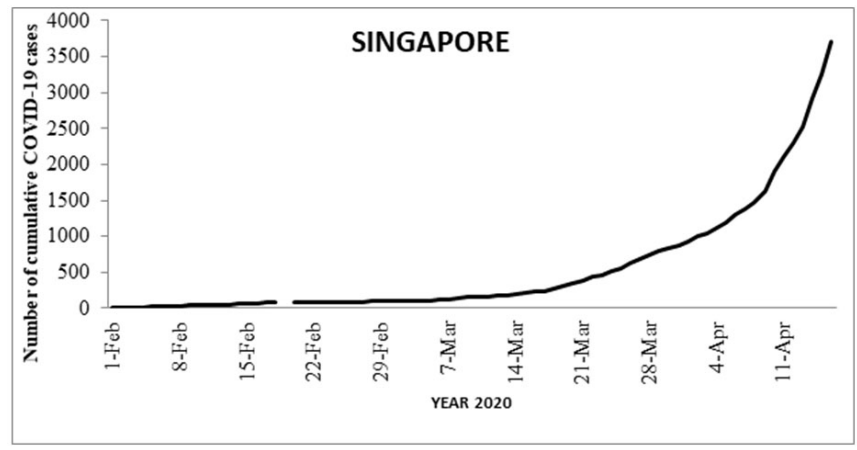

Figure 3: Variation of COVID-19 cases confirmed in Singapore based on the WHO report.

Australia: on $25^{\text {th }}$ January 2020 first case confirmed in Australia. The number of cases reported in the first 49 days is very low. Later it increasing sharply and led to the closing of non-essential business on March 23 and strict lockdown from March 31, 2020. The conformed cases on $23^{\text {rd }}$ March are 1396. From Figure 4 it is observed that initially, the rate of increment of the covid-19 cases are low until 14 march 2020. Later there is a sharp rise observed in the conformed cases even though there is a lockdown. 


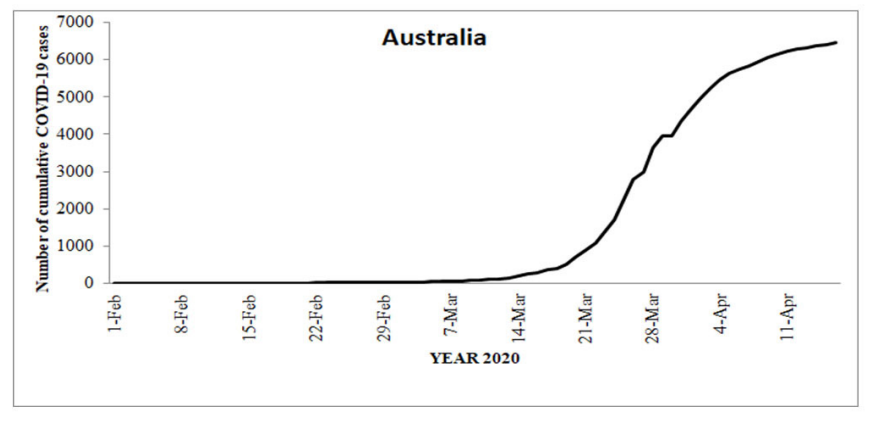

Figure 4: Variation of COVID-19 cases confirmed in Australia based on WHO report.

\section{Group 2: The cases reported between 10,000 to 50000 on or before $16^{\text {th }}$ April}

India: In India, the first case reported on 29 January 2020. Though the country confirmed its first case in January the increment of cases is very slow until $20^{\text {th }}$ March (52 days daily reporting cases are below 100). The Indian government imposed a lockdown of the total country on March 24 to maintain social distancing. Even many good efforts put by the government such as avoiding holi like cultural festivals, restrictions on travel, prayers etc. to prevent the spreading of virus and the country summer temperature is $>35^{\circ} \mathrm{C}$ the daily conformed cases raised to 1300 (Figure 5). Therefore the researchers must study there is any link between the period of mutation of the virus and the number of cases rising.

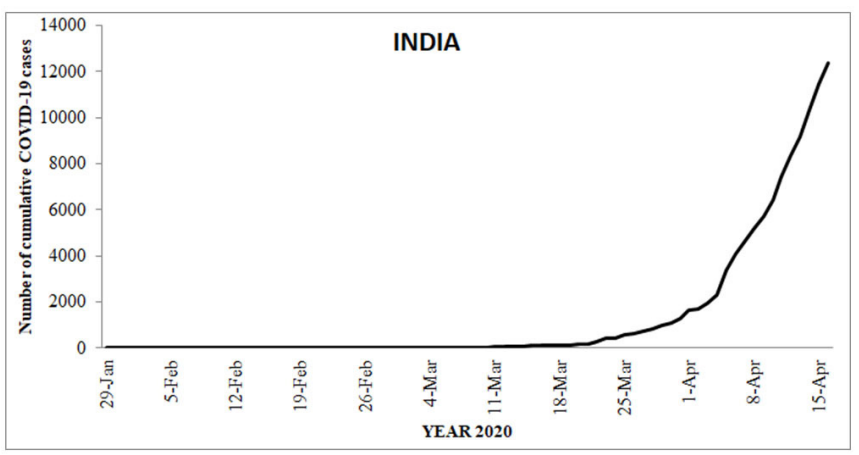

Figure 5: Variation of COVID-19 cases confirmed in India based on the WHO report.

Republic of Korea: From figure 7, it is observed that between 19 January and 18 February 2020 only 30 cases are reported in the republic of Korea. Suddenly the cases are jumped to thousands and now the reporting cases are decreased due to the efforts of the Korea government by strictly following the social distance. From figure 6, it is also observed that the mutation period of the coronavirus is less compared to other countries i.e., only 30 days and in these 30 days, the number also doubled where it does not happen in other countries. Maybe it is one of the reasons for the sudden spike of cases and reducing the increment in the short interval of time.

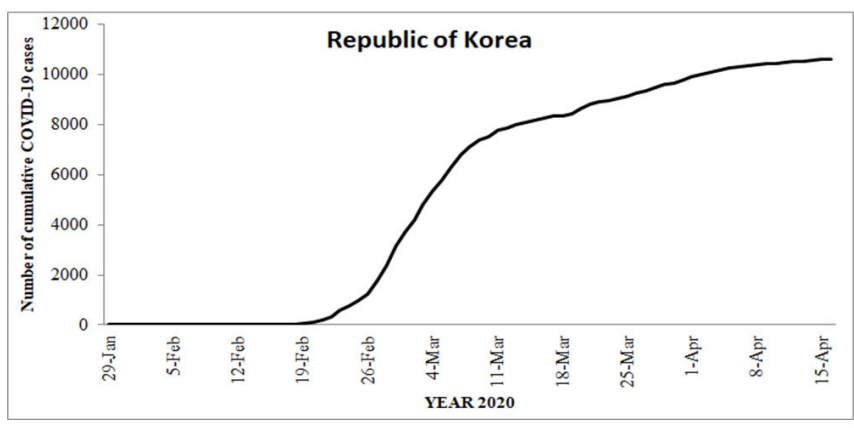

Figure 6: Variation of COVID-19 cases confirmed in the Republic of Korea based on WHO report.

Belgium: This country is hardest hit by the pandemic. Even though the first case reported on $4^{\text {th }}$ February 2020 the sudden spike started from $11^{\text {th }}$ March. Nearly 40 days the rate of rising of the cases is very slow. Now the daily confirmed cases rose to nearly 2500 even though the Belgium government strictly followed the social distance. It is very important to study that why the initial rate is slow and how it will effect on the following increment rate. Because in the Belgium the first case report on $4^{\text {th }}$ February and second case on $1^{\text {st }}$ March (nearly 20 days) (Figure 7). Interestingly a sudden spike is observed from $17^{\text {th }}$ March to till date.

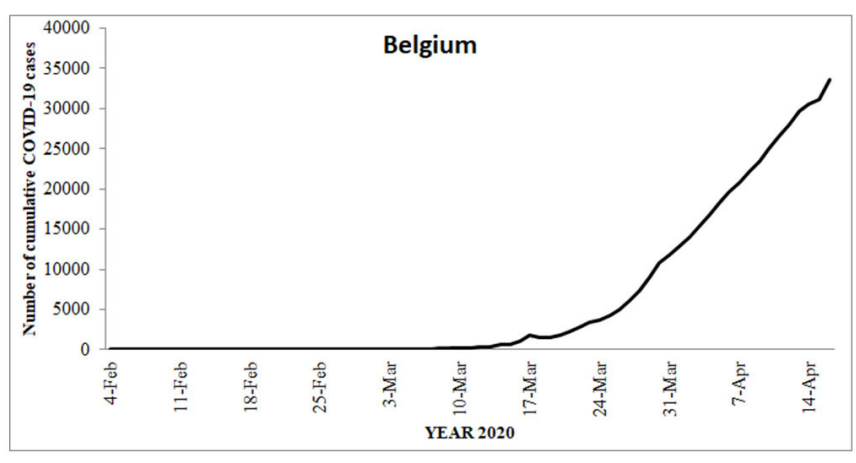

Figure 7: Variation of COVID-19 cases confirmed in Belgium based on the WHO report.

Canada: On $15^{\text {th }}$ January the first case of COVID-19 confirmed in Canada. The sharp rise in graph 9 is observed from 13 March 2020. Initially, the cases rise is gradual among travellers returning to Canada from countries where outbreaks of COVID-19 were already occurring and their close contacts (Figure 8). The number of cases increased sharply in March as the virus began to spread from one person to another in Canadian communities. It also observed that initially, the virus taking nearly one month time for mutation from the first person for survival and then started for communities. 


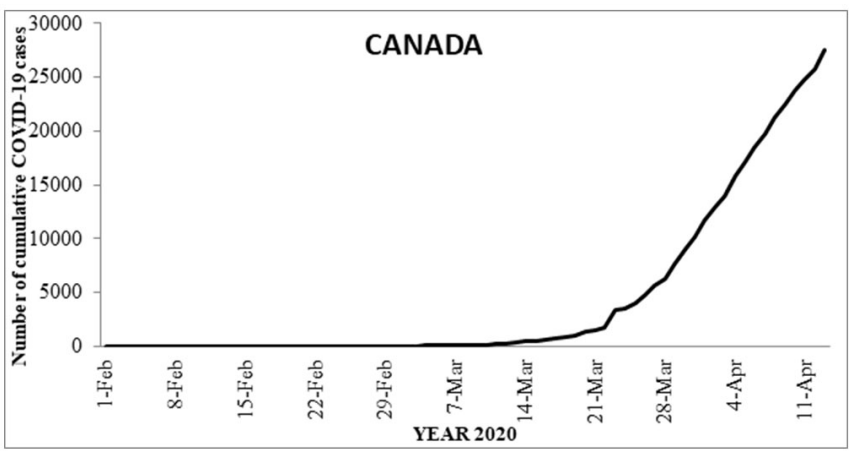

Figure 8: Variation of COVID-19 cases confirmed in Canada based on the WHO report.

Group 3: The cases reported above 50,000 on $16^{\text {th }}$ April 2020

USA: The first novel coronavirus is confirmed on 20 January 2020 in Washington of the United States of America. Nearly 58 days the daily number of confirmed cases is very low. After $19^{\text {th }}$ March the biggest change observed in the cases reporting daily nearly 25,000 cases even though the borders of the country closed in early February (Figure 9). The community transmission is severe in the USA. It is due to the virus entered the country in late January and stayed in the incubation period till march 19 without causing much effect in local transmission. After the incubation period, the virus started spreading and increases the death toll in the country.

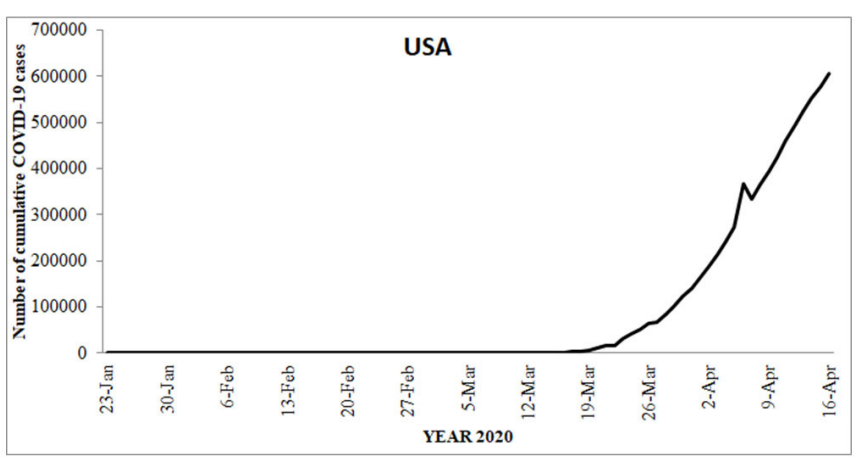

Figure 9: Variation of COVID-19 cases confirmed in USA based on WHO report.

Italy: The first two covid-19 cases are reported in Rome. Up to $23^{\text {rd }}$ February the total conformed cases are below 100. From the available data it is also observed that the conformed cases are below compared to republic of korea. But there is a sudden rise is observed in the cases from march $7^{\text {th }}$ 2020. In Italy the local transmission is severe and increases the death toll.

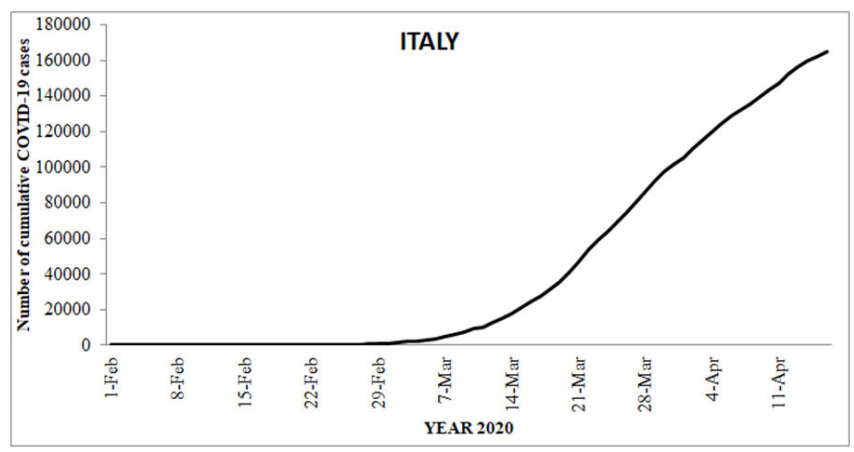

Figure 10: Variation of COVID-19 cases confirmed in the USA based on WHO report.

France: pandemic coronavirus reached France on $24^{\text {th }}$ January 2020. In France also the initial increment rate is slow until $7^{\text {th }}$ March. Due to the rapid rise observed from $12^{\text {th }}$ March, The French president announced the closing of non-essential business to maintain social distance as a preventive measure of corona spread. At the time of shutting the country, the conformed cases are 2296 and daily reporting 400 cases new$1 y$. Even though the government put many efforts from $12^{\text {th }}$ March, local severe transmission in the country very high reporting over 1,68,000 confirmed cases and 19,323 deaths on April 18. The reason for this the virus has spread and held in the incubation period for 43 days in the country.

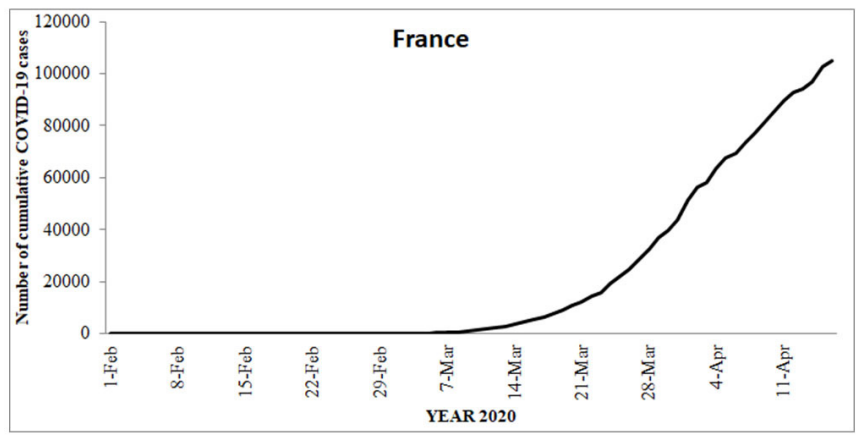

Figure 11: Variation of COVID-19 cases confirmed in France based on WHO report.

Germany: COVID-19 hit Germany with force. Total of 92000 cases report in the country on $18^{\text {th }}$ April 2020. The country stood in fourth place after USA, Italy and spain. From the figure 12 it is observed that initially the spreading cases are low upto march 10 and observed a sudden spike in the cases. 


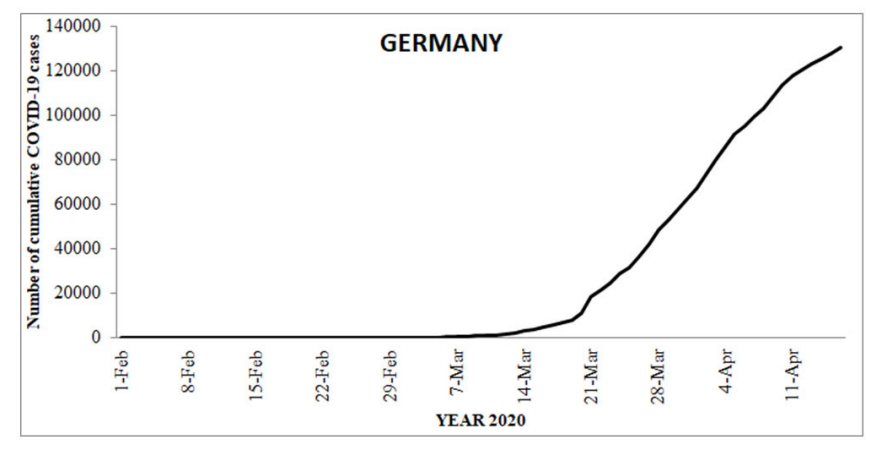

Figure 12: Variation of COVID-19 cases confirmed in Germany based on WHO report

United Kingdom: the first conformed COVID-19 case is on 29 January 2020 . Till $16^{\text {th }}$ march, the cases are low and started rising cases. Local transmission of the virus is observed on February 28. At present (18 April) the number of cases in the UK crosses 1,00,000 even though the government avoiding mass gathering from March 12.

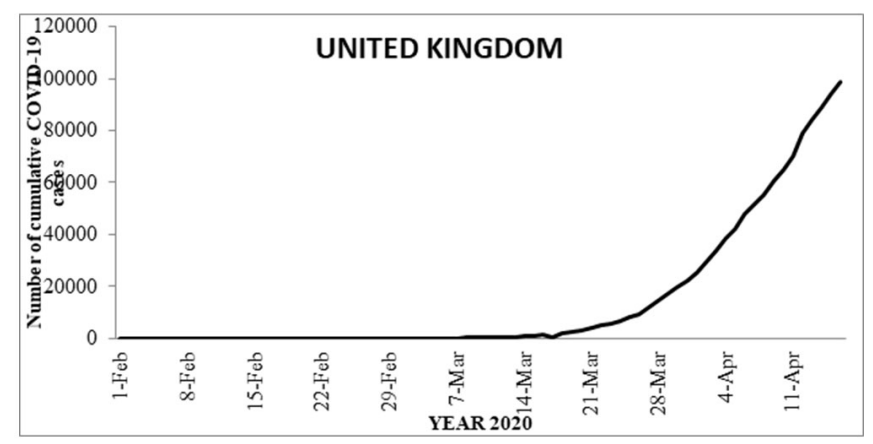

Figure 13: Variation of COVID-19 cases confirmed in UK based on WHO report.

\section{CONCLUSION}

The quick spreading of the Covid-19 infection around the planet is conceivable because of its transformed nature and size of the minuscule infection molecule. There is a sudden surge in Covid-19 cases across the globe since the middle of March due to the considerable travel history of the infected patients. Despite the Governments stringent efforts to control the rapid spread of infection by imposing lockdown in many countries, the Corona cases are abruptly increasing since March $12^{\text {th }}$ due to the migration of people across countries. Hence it is required to understand the replication of the mutated virus to predict the aetiology behind the sudden spike in corona cases across the globe.

\section{ACKNOWLEDGEMENTS}

The authors are grateful to the management of Marri Laxman Reddy Institute of Technology and Management for providing their valuable support in designing the Review article. The authors are also grateful to authors/editors/publishers of all those articles, journals and books from where the literature for this article has been reviewed and discussed.

Conflict of Interests: This is to inform you that the authors declare that they have no conflict of interests regarding this article.

\section{Financial Support: NIL}

\section{Author's Contribution}

Dr. Varalakshmi Vajja has conceptualized, designed and drafted the review article. Dr. Kadiri Sunil Kumar has contributed to data acquisition and critical revision of the manuscript.

\section{REFERENCES}

1. Hui DS, Azhar EI, Madani TA, Ntoumi F, Kock R, Dar O, et al. The continuing 2019-nCoV epidemic threat of novel coronaviruses to global health-The latest 2019 novel coronavirus outbreak in Wuhan, China. Int J Infect Dis 2020;91(1):264-266.

2. Amiri AS, Akram M, Bems M. COVID-19: The challenges of human life. Social Work Soc Sci Rev 2020;17(1):1-17

3. Chauhan S. Comprehensive review of coronavirus disease 2019 (COVID-19). Biomed J 2020;43(4):334-340.

4. Asadi S, Wexler AS, Cappa CD, Barreda S, Bouvier NM, Ristenpart WD. Aerosol emission and super emissions during human speech increase with voice loudness. Sci Rep 2019;9(1):2348.

5. Joyner MJ, Wright RS, Fairweather D, Senefeld JW, Bruno KA, Klassen SA, et al. Early safety indicators of COVID-19 convalescent plasma in 5000 patients. J Clin Invest 2020;130(9):47914797.

6. Atique S, Bautista JR, Block LJ, Lee JJ, Lozada PE. A nursing informatics response to COVID-19: perspectives from five regions of the world. J Am Med Assoc 2020;76(10):2462-2468

7. James M, Marguerite L, Tomasz Z, James B. Pharmacologic treatments for coronavirus disease 2019 (COVID-19). J Am Med Assoc 2020;323(18):1824-1836.

8. Yeager A. Lost smell and taste hint COVID-19 can target the nervous system. The Scientist Magazine 2020

9. Varalakshmi V, Sarvanan M and Sunil Kumar K. Reasons for increasing corona cases during lockdown case study of India. J Am Med Assoc 2020;13(11):76-78.

10. Rashid A. Dynamics of Infectivity and Fatality of COVID-19 Pandemic. Int J Curr Res Rev 2021;13(5):109-114. 